\title{
7 The Greed
}

After liberation we had no one but the three of us: my aunt, Laci and I. When we went back Mrs. Strucky received my aunt in my aunt's silk gown and served her tea in my grandmother's Rosenthal tea set. ${ }^{271}$

The Dely trial's focus was on the unprecedented and brutal murders at Csengery 64, but the court process failed to clarify who fired and how many people died. In the Szamocseta trial the focus was on financial $\operatorname{loss}^{272}$ and restitution, and the Strucky-Szamocseta families were indeed sentenced for the confiscation of assets, but because of an administrative mistake the verdict was never executed. Analysing the dispossession of Jews in Hungary is absent from the international literature, therefore this case study is even more valuable as it shows the process by which the state and individuals enriched themselves by creating legal and psychological circumstances whereby the owners gave over their property to them. ${ }^{273}$ This process is labelled by Frank Bajohr as the "race for personal enrichment" (Bereicherungswettlauf). ${ }^{274}$ Thus the war profiteer family could keep all the wealth they plundered: everything they stole from those who never returned and additionally those items the loss of which they blamed on the Arrow Cross or the Russians. The stolen goods were quickly liquidated so when the Struckys moved out from Csengery 64 the eager tenants could not recognize anything other than a perhaps familiar looking carpet among the Struckys' packed-up items.

There were no particularly wealthy people in Csengery 64, as most of the tenants belonged to the lower middle class. During the hearings they regretted the loss of chrome watches, crocheted tablecloths, embroidered duvet covers and undergarments. ${ }^{275}$ The fact that the first things the janitors grabbed from

271 Miklós Bodor's personal letter.

272 On the systematic dispossession of Hungarian Jewry, see Kádár Gábor and Vági Zoltán, Aranyvonat. Fejezetek a zsidóvagyon történetéből (Budapest: Osiris Kiadó, 2001), Kádár Gábor and Vági Zoltán, Hullarablás. A magyar zsidók gazdasági megsemmisítése (Budapest: Jaffa Kiadó, 2005), Rigó Róbert, “A zsidóvagyon sorsa Kecskeméten,” Forrás 40.9 (2008): 42-80, Bibó István, Zsidókérdés Magyarországon 1944 után (Budapest: Katalizátor Iroda, 1994), 18.

273 Christoph Kreutzmüller and Jonathan R. Zatlin, ed., Dispossession: Plundering German Jewry, 1933-1953 (Ann Arbor: University of Michigan Press, 2020).

274 The original German phrase, found in Frank Bajohr, “Arisierung” in Hamburg. Die Verdrängung der jüdischen Unternehmer 1933-45 (Hamburg: Hans Christians Verlag, 1997). Quoted in in troduction to Christoph Kreutzmüller and Jonathan R Zatlin, ed., Dispossession : Plundering German Jewry, 1933-1953 (Ann Arbor: University of Michigan Press, 2020), 9.

275 BFL 19273/1949. 20.

https://doi.org/10.1515/9783110687552-009 
the abandoned apartments were undergarments shows the intimacy of these murders. The items were usually returned later to their owners. But generally, it was very hard to trace the route of particular items. In the steel safe deposit box of the allegedly wealthy Steiners there were supposedly only 800 pengös, which may explain the sudden aggression of the armed men. ${ }^{276}$ In the Grünfeld's Wertheim safe the intruders found 3200 pengös and 13 bottles of spirits (pálinka) and the Grünfelds were not shot. ${ }^{277}$ In her testimony, Mrs. Steiner mentioned that the armed men stole her 'Floris' chocolate and her sister in law's gown. ${ }^{278}$ Gowns often played a central role in the testimonies, perhaps because the post-war stories were primarily women's stories (way fewer men returned from deportation) and personal items like gowns have an identity-making effect with their intimacy. The engine of the events, Andor Lichter, missed his typewriter the most, but later he found it in the Struckys' apartment alongside several other typewriters.

Unquestionably their apartments were the returned tenants' most valuable assets: in war-ruined Budapest, inhabitable apartments represented great value. As already discussed, the Csengery 64 tenants often changed between June and November 1944 when the deportations started. After the deportations a total of 34 of the building's apartments were assigned to new tenants because those were "forsaken by the persecuted." 279 The new tenants paid a considerable rent for these apartments and for months on end János Pál, the new janitor, collected that rent and gave it to the Strucky family instead of the Jewish owner of the house. ${ }^{280}$

\subsection{The birth of wealth}

At the beginning, the Struckys perhaps felt that it was not worth staying in a yellow star house as the sole Christian family. Soon though as the ghettoization began they had more and more opportunities for profiteering. The families who had to move into the yellow star houses were crammed together and they stored their assets in the apartments and in lockable cellars. Some tenants gave part of their belongings to the janitor for safekeeping. These transactions were all trust-based as the tenants could not ask for a receipt. Some tenants

276 BFL 2442/1947. 35.

277 BFL 19273/1949. 48.

278 BFL 2442/1947. 35.

279 BFL 19273/1949. 61.

280 BFL 19273/1949. 21. Mrs. Pál's testimony, January 6, 1946. 
gave them their apartment keys. The janitors took advantage of the trust they accumulated before the Jewish Acts were put in effect.

The most feasible explanation for the fact that many Christian janitor families, who could have moved elsewhere, chose to stay in the yellow star houses, is that they recognized that their position could help them become lucrative money-makers. Did they know that the Jewish tenants would be deported? They most probably didn't, but they used the law to their advantage when the systematic dispossession of the tenants had begun. One tenant remembers:

[T]he Jellinek family moved to the ghetto. Soon after they left their apartment I was coming upstairs to my own apartment and on the way, I glanced into theirs because the door was wide open. In the anteroom I saw Nándor Szamocseta on the top of a chair as he handed things from the top of a wardrobe to his parents who were both there with him. ${ }^{281}$

The janitors requested money for all their otherwise free services. Thus, the yellow star houses turned into "private prisons" where the tenants lived according to rules set by the janitors. The aim of these rules was constant monitoring and ceaseless theft. For instance, one had to pay 200 pengös (which was then a very lavish monthly salary) to be let out of the house, but Strucky often took the money and still did not open the gate. ${ }^{282}$

Confinement increased vulnerability and the Strucky-Szamocseta families were prepared to reap harvest of the situation's psychological effects, which is what happened on October 15, 1944. Although Horthy's proclamation seemed to have signaled the end of their little private business, the later news about the Szálasi coup promised further increase of wealth and a quick end to the mortgage on their Göd house. Whether it was Mrs. Strucky’s lodger Széplaki who reported on the Jewish tenants is unknown, but it is certain that as soon as the first group of tenants was taken to the police station the Struckys took the opportunity.

First, they looted the dead and their apartments - they were aware that this was something they could easily blame on the leaving Arrow Cross and SS soldiers. When the hiding tenants emerged, they locked them in the air raid shelter in order to be able to search and rob the apartments undisturbed. In the meantime, in the air raid shelter the still deeply shocked Jewish tenants gathered money to be able to buy Nándor Szamocseta's benevolence - as suggested by Nándor Szamocseta himself. The fact that the Arrow Cross or SS troops returned to the house provided a great cover story for the janitors as they could claim that

281 BFL 19273/1949. 227. Mrs. Singer's testimony.

282 BFL 19273/1949. 59. 
the armed men robbed the apartments too. This was one of the reasons why the tenants did not openly confront them challenging their version of the events.

The Sterns' woolen blanket became the symbol of the Csengery 64 robbery. $\mathrm{Mr}$ and Mrs. Stern were either holding it when they were shot, or their dead bodies were covered with it. According to a witness it was not a blanket but a Persian rug that soaked up their blood. This would explain why Mrs. Strucky kept it. Strucky picked it up, Mrs. Strucky washed it and it was dried hanging on the courtyard's carpet-beater for several days. The blanket or rug that was still in their possession during the Dely trial ("because no one wanted it") symbolized the bloody redistribution of wealth that took place in Csengery 64 .

When the house's tenants were herded away, the Struckys settled into the new situation. However, to their great surprise on October 18 and 19 the tenants came back. After that the tenants were consciously preparing for their future deportation and entrusted more and more of their assets to the only family they could turn to for assistance, the janitors. The deportations started on November 5 and went on until November 20. In the chaos of the deportations the janitors offered a helping hand as trustworthy "friends." Around this time, they had already collaborated with János Pál and his wife, the future janitors of Csengery 64.

[W]hen we only had minutes to leave the house the present time janitor, János Pál and his wife intruded into my apartment, they opened my wardrobes and he started to rummage in them and then he took clothing items that he liked, underwear and shirts etc. and left with them but beforehand told his wife that she could take whatever she felt like. When I returned to my request Mrs. Pál gave back part of my belongings and also said that she is ready to testify that Mrs. Strucky took my white angora yarn with the knitting needles. After the battle I saw my white angora yarn on Éva Strucky, knitted. This was suspicious because Strucky did not work in 1944 only Éva Strucky worked in the House Office, where she issued apartments to the incomers of the Szálasi-era, including their relatives, unlawfully, so it was not likely that they would have had the means to buy something like that not to mention that back then it was not possible to buy angora yarn as the stores were closed. When the Germans were finally ousted from the country in the spring of 1945 then Mrs. Strucky all at once remembered to bring back my crocheted tablecloth and my sister in law's two embroidered duvet covers; Mrs. Szamocseta returned my sister in law's gown, my brother's Royal typewriter, and they said that these items were in their apartment for safekeeping. Beforehand they did not remember that although the house overseer [Lichter] warned them several times. They always said that the Russians robbed the house. ${ }^{283}$

283 BFL 19273/1949. 25. Mrs. Gábor’s testimony. 
When everyone else was deported from the house the larger items such as the furniture and greater objects could be safely sold off. But first the Struckys moved upstairs into the nicest apartment of the building, the Krámer's, and to their own place they installed newcomers in the house, the new janitors, Pál János and his wife, who were completely at their mercy and followed each of their commands. According to the testimonies "the assets of the murdered Stern family were taken away by Arrow Cross trucks,"284 and "they went upstairs in the forsaken apartments and gathered the more valuable items."285

Éva, their daughter, was employed at the House Office responsible for the redistribution of Jewish property, the "emptied" apartments. She collaborated in assigning these apartments in the house to trustworthy people who accepted the Strucky family's unquestionable rule in the building. Still, not every new tenant robbed the apartment they inhabited. Sándor Bán, a policeman, lived in Lichter's apartment for a short while. Strucky gave him the keys to the apartment together with an inventory list of all equipment. Lichter got everything back: "Bán returned all my belongings on the inventory list."286 The inventory meant responsibility, but it was seldom that such a list was put together. Most of the tenants who returned after the liberation found empty wardrobes, cellars and pantries. $^{287}$

Nándor Szamocseta also acquired an allegedly empty apartment in the neighborhood that he filled with furniture and other items. Most probably some of the robbed goods were taken to the Strucky's Göd house. As stated, Nándor Szamocseta started working as a driver, and the trucks that he fixed up could provide a great help moving the stolen furniture of Csengery 64. Stolen goods had a well-developed black market by then: the larger and easily recognizable furniture and carpets were immediately taken to the countryside. In the mayhem of war, the chances of being caught were minimal, plus it was easy to attribute the robberies to the Arrow Cross or later to the Russians when the returned Jews looked for their assets. Mrs. Strucky confirmed:

After liberation Russian soldiers installed phone cables in the house and while they worked the gate was wide open. In the meantime, anyone could enter the house and we could not

284 BFL 19273/1949. 47. Mrs. Grünberg's testimony.

285 BFL 19273/1949. 57.

286 BFL 19273/1949. 200. Lichter's testimony.

287 For more, see Borbála Klacsmann, "Abandoned, confiscated, and stolen property: JewishGentile relations in Hungary as reflected in restitution letters,” Holocaust Studies 23 (2017): 133148. 
prevent robberies. When the Krámers were deported Mrs. Krámer asked me to safeguard their furniture, therefore we moved into their apartment. ${ }^{288}$

On the other hand, according to Mrs. Krámer's version, the Struckys not only appropriated their belongings including their food supplies but they moved into their apartment and did not want to let the Krámers back. When the family returned Mrs. Strucky shouted at them: "My sweet lord what shall I do with you now?” However, at least the apartment's equipment was preserved. ${ }^{289}$

When the returned tenants wanted to know the whereabouts of their items, the Struckys pointed at the new janitors, the Páls, and the Páls pointed at the Struckys:

When I returned into my apartment after liberation, I saw that much of my belongings disappeared. When I inquired the janitors told it was the Struckys and the Struckys told it was the janitors. So I never found my assets. ${ }^{290}$

[A]fter liberation I found at the new janitor's wife, Mrs. Pál, or rather I saw her wearing my daughter's blouse and shoes that she returned upon my request. She said that she got them from the Russians. ${ }^{291}$

The intimacy of the robberies affected the two janitors differently. Strucky, who always liked to drink, reached for the bottle increasingly often and one night he yelled drunk at his wife: "You stole everything from the Jews!"292 At the same time his wife increasingly enjoyed her power and kept on complaining about her husband's meekness.

\subsection{The loss of wealth}

Andor Lichter's return to Budapest after the liberation marked a turning point in the wrangle over the stolen assets. It certainly did not contribute to the establishment of a good relationship that Mrs. Strucky received Lichter in the gown of his wife who was killed in Bergen-Belsen. ${ }^{293}$ As soon as he arrived Lichter became the house overseer, the elected representative of the house who supervised the

288 BFL 19273/1949. 73-74. Mrs. Strucky's testimony.

289 Interview with Magda Kun, October 7, 2005.

290 BFL 19273/1949. 62. Mrs. Propper's testimony.

291 BFL 19273/1949. 226. Mrs. Faragó's testimony.

292 BFL 19273/1949. 29. Mrs. Krámer’s and Mrs. Sárdi’s testimonies (BFL 19273/1949. 263.): Strucky "was often drunk."

293 Magda Kun's personal statement. 
janitor, thus he had the authority to demand the return of his stolen assets, among them his typewriter. By April some of his items, e.g. the typewriter was returned.

After liberation it became part of the returned people's everyday routine that they looked for their belongings that were either stolen or that they themselves had handed over for safekeeping before the deportations. In parallel they tried to convince the new tenants of their apartments to move out. A survivor remembered:

We went back to our old apartment in the Csengery. In the meantime, things happened. It was a separated section of the apartment. Someone moved into the other half, used it but then left. A woman with a small child. She had a hard time leaving... It was not about big things: what she returned me was something from my father. That hurt me. ${ }^{294}$

Another stated:

After liberation Mrs. Szamocseta handed over a typewriter and told me that she was unsure whether it was mine, and later my sister in law also got back a few clothing items again from the Szamocsetas. Later we also got back some bedding and undergarments from the Struckys. All of them said that the apartments were robbed by the Arrow Cross and then by the Russians, still, we found our own underwear in their apartments. ${ }^{295}$

After many failed attempts to reclaim their belongings the house overseer and the angry tenants held a house search at the Struckys'. This most probably contributed to the Struckys' quick move from Csengery Street to their house in Göd, which by that time was free from its mortgage. In Mrs. Strucky's words: “[W]hen after liberation the returned persecuted tenants held a house search in our apartment they found nothing. Whatever we had for safekeeping I gave back to their rightful owners right after their return.” 296

The assets were of very different value. Some lost carpets and furniture, others lost clothing items such as silk neckties, and there was someone who looked for a barrel of lard (which could be a lifesaver then). ${ }^{297}$ For instance, from the

294 Interview with Edit Rosenberg, August 13, 2007.

295 BFL 19273/1949. 30., Mrs. Gábor’s testimony

296 BFL 19273/1949. 72. Ilona Bodor also stated that what she gave to Strucky she received back, but the contents of her wardrobes that she entrusted to Mrs. Strucky were completely gone. (BFL 19273/1949. 222.)

297 Mrs. Schwartz: "While I was deported my apartment and several other apartments in the house were robbed. Once I took a barrel of lard to Mrs. Strucky but I never got it back. When I was deported, I messaged Mrs. Strucky to send that lard after me but she said that the Arrow Cross took it.” 19273/1949. 78. 
Krámer apartment the four families' whole food supply disappeared on October 16, 1944. Later, when the Krámers were hiding in the Szamocseta's apartment, they had to pay for their own food. ${ }^{298}$ The objects were strictly kept count of as Mrs. Rosenberg on May 10, 1947 still stated that some of her items were at the Struckys. ${ }^{299}$

The Szamocseta trial was a late trial in the history of the People's Tribunals. By then it was more comfortable to frame the trial as an account of what happened in the Csengery Street primarily for financial accountability. The emotions disappeared form the recorded texts, the witnesses cold headedly listed their financial losses and the endured injustices. Because of the earlier Dely trial, by this time the stories became narratable and they took on a standardized form. Nevertheless, the returned tenants were deeply hurt, and they harbored a lot of bitter hatred too. From the interviews it is clear that the survivors were not satisfied with the operation of the People's Tribunals, the process of compensation and, first of all, with the fact that the janitor family could get away with all those goods they robbed from the tenants. This dissatisfaction was discussed at home and among relatives. What could remedy those feelings - and whether the People's Tribunal, which at the time had no alternative, was suitable for that - remains a question. 